\title{
PERLINDUNGAN HUKUM BAGI KONSUMEN DALAM JUAL BELI SECARA ONLINE MENURUT UNDANG-UNDANG NOMOR 8 TAHUN 1999 TENTANG PERLINDUNGAN KONSUMEN
}

\author{
Ainul Masruroh \\ Fakultas Hukum \\ Universitas Islam Darul 'Ulum Lamongan \\ Post.El.ainul_masruroh@yahoo.com
}

\begin{abstract}
The purpose of this study is to explain and understand the regulation of online trading in Indonesia and to juridically analyze how legal protection for consumers in buying and selling online in accordance with Law Number 8 of 1999 concerning Consumer Protection. The method used in this thesis is a type of normative juridical research. The approach to the problem used is the legal approach (sculpture approach) and the conceptual approach (conceptual approach). This thesis uses three types of legal material sources, namely primary legal material, secondary legal material and tertiary legal material. The conclusions of this study are: that online buying and selling transactions have developed rapidly in Indonesian jurisdiction and users of these transactions are large enough to need special rules to protect transaction activities so that consumers protect themselves from all kinds of bad faith and Indonesia itself has a legal basis regarding consumer protection, including Law Number 8 of 1999 concerning Consumer Protection. Consumers who buy and sell online or E-Commerce must be given special protection that can protect business people who have bad intentions in making online buying and selling transactions.
\end{abstract}

Keywords: protection, consumers, buying and selling, online

\begin{abstract}
Abstrak : Tujuan penelitian ini adalah untuk menjelaskan dan memahami pengaturan perdagangan online di Indonesia dan untuk menganalisis secara yuridis bagaimana perlindungan hukum bagi konsumen dalam membeli dan menjual secara online sesuai dengan Undang-Undang Nomor 8 Tahun 1999 tentang Perlindungan Konsumen. Metode yang digunakan dalam tesis ini adalah jenis penelitian yuridis normatif. Pendekatan masalah yang digunakan adalah pendekatan hukum (pendekatan patung) dan pendekatan konseptual (pendekatan konseptual). Tesis ini menggunakan tiga jenis sumber bahan hukum, yaitu bahan hukum primer, bahan hukum sekunder dan bahan hukum tersier. Simpulan dari penelitian ini adalah: bahwa transaksi jual beli online telah berkembang pesat di wilayah hukum Indonesia dan pengguna transaksi ini cukup besar sehingga perlu ada aturan khusus yang melindungi kegiatan transaksi sehingga konsumen melindungi diri dari segala macam itikad buruk dan Indonesia sendiri sebenarnya memiliki dasar hukum mengenai perlindungan konsumen, antara lain Undang-Undang Nomor 8 Tahun 1999 tentang Perlindungan Konsumen. Konsumen yang membeli dan menjual secara online atau E-Commerce harus diberi perlindungan khusus yang dapat melindungi dari pelaku bisnis yang memiliki niat buruk dalam melakukan transaksi jual beli online.
\end{abstract}

Kata kunci: perlindungan, konsumen, jual beli, online 


\section{PENDAHULUAN}

Internet membawa perekonomian dunia memasuki babak baru yang lebih populer dengan istilah digital economic atau ekonomi digital. Keberadaannya ditandai dengan semakin maraknya kegiatan perekonomian yang memanfaatkan internet sebagai media komunikasi. Perdagangan misalnya, semakin banyak mengandalkan perdagangan elektronik atau electronic commerce (e-commerce) sebagai media transaksi. ${ }^{1}$

Perdagangan yang berbasis teknologi canggih, e-commerce telah mereformasi perdagangan konvensional di mana interaksi antara konsumen dan perusahaan yang sebelumnya dilakukan secara langsung menjadi interaksi yang tidak langsung. E-commerce telah merubah paradigma bisnis klasik dengan menumbuhkan model - model interaksi antara produsen dan konsumen di dunia virtual. Sistem perdagangan yang dipakai dalam e-commerce dirancang untuk menandatangani kesepakatan secara elektronik. Penandatanganan elektronik ini dirancang mulai dari saat pembelian, pemeriksaan dan pengiriman. ${ }^{2}$

Pembangunan dan perkembangan perekonomian di bidang perindustrian dan perdagangan nasional telah menghasilkan berbagai variasi barang dan jasa yang dapat dikonsumsi. Ditambah dengan globalisasi dan perdagangan bebas yang didukung oleh kemajuan teknologi telekomunikasi

\footnotetext{
${ }^{1}$ Richardus Eko Indrajit, E-Commerce: Kiat dan Strategi Bisnis di Dunia Maya, PT. Elex Media Komputindo, Jakarta, 2001, hlm. 33.

2 Abdul Halim Barkatullah dan Teguh

Prasetyo, Bisnis E-Commerce: Studi

Sistem Keamanan dan Hukum di Indonesia, Pustaka Pelajar, Yogyakarta, 2005, hlm. vii.
}

kiranya memperluas ruang gerak arus transaksi barang dan jasa. ${ }^{3}$

Setelah internet terbuka bagi masyarakat luas, internet mulai digunakan juga untuk kepentingan perdagangan. Setidaknya ada dua hal yang mendorong kegiatan perdagangan dalam kaitannya dengan kemajuan teknologi yaitu meningkatnya permintaan atas produk-produk teknologi itu sendiri dan kemudahan untuk melakukan transaksi perdagangan. ${ }^{4}$ Selain itu, Perkembangan teknologi informasi tersebut sangat pesat dan telah membawa banyak perubahan. Perubahan pola kehidupan tersebut terjadi hampir di semua bidang, baik sosial, budaya, ekonomi, maupun bidang lainnya. Perubahan tersebut antara lain dengan berkembangnya penggunaan teknologi internet (telematika) yang merupakan salah satu bagian dari perkembangan teknologi informasi.

Salah satu perubahan yang sangat besar akibat berkembangnya teknologi informasi adalah dalam bidang ekonomi. Perkembangan teknologi informasi secara signifikan telah mengubah sistem ekonomi konvensional menjadi sistem ekonomi digital. Sistem digital ini memungkinkan dunia usaha melakukan suatu transaksi dengan menggunakan media elektronik yang lebih menawarkan kemudahan, kecepatan, dan efisiensi. Saat ini banyak dijumpai transaksitransaksi perdagangan modern yang menggunakan teknologi sebagai medianya atau yang lazim disebut transaksi elektronik atau perdagangan

\footnotetext{
${ }^{3}$ Ahmadi Miru \& Sutarman Yodo, 2011, Hukum Perlindungan Konsumen, PT. Raja Wali Grafindo Persada, Jakarta, Hal.37.

${ }^{4}$ Asril Sitompul, Hukum Internet (Pengenal Mengenai Masalah Hukum di Cyberspace), Cetakan II, Bandung : PT. Citra Aditya Bakti, 2004, hlm. 4.
} 
elektronik atau electronic commerce (ecommerce).

Pengertian e-commerce sendiri adalah segala bentuk transaksi perdagangan atau perniagaan barang dan jasa dengan menggunakan media elektronik. Dampak dari adanya internet sebagai hasil dari kemajuan perkembangan teknologi informasi bagi konsumen di satu sisi telah mengubah perilaku konsumen menjadi semakin kritis dan selektif dalam menentukan produk yang akan dipilihnya. Begitu pula bagi produsen, kemajuan ini memberi dampak positif dalam memudahkan pemasaran produk sehingga dapat menghemat biaya dan waktu.

Dengan maraknya dan berkembangnya e-commerce menghasilkan beberapa bentuk jual beli online yang tersedia saat ini antara lain:

1. Lazada.co.id

2. Tokopedia.com

3. Bukalapak.com

\section{Lazada.co.id}

Lazada merupakan situs belanja online yang menawarkan berbagai macam jenis produk, mulai dari elektronik, buku, mainan anak, perlengkapan bayi, alat kesehatan, produk kecantikan, peralatan rumah tangga, perlengkapan traveling dan olahraga. Didirikan sejak 2012 lalu, Lazada merupakan salah satu cabang dari jaringan retail online LAZADA Asia Tenggara yang merupakan cabang anak perusahaan internet Jerman yaitu Rocket Internet.

\section{Tokopedia.com}

PT Tokopedia didirikan pada 6 Februari 2009, sedangkan Tokopedia.com secara resmi diperkenalkan ke Publik pada 17 Agustus 2009. Seperti yang sudah diketahui tokopedia.com merupakan salah satu mal online di Indonesia yang mengusung model bisnis marketplace. Sejak diluncurkan hingga akhir 2015, layanan dasar Tokopedia bisa digunakan oleh semua orang secara gratis.

\section{Bukalapak.com}

Bukalapak merupakan salah satu pasar daring (online marketplace) terkemuka di Indonesia yang dimiliki dan dijalankan oleh PT. Bukalapak. Seperti halnya situs layanan jual beli dengan model bisnis consumer-to-consumer (C2C ), Bukalapak menyediakan sarana penjualan dari konsumen ke konsumen di mana pun. Siapa pun bisa membuka toko daring untuk kemudian melayani calon pembeli dari seluruh Indonesia baik satuan ataupun dalam jumlah banyak. Pengguna perorangan ataupun perusahaan dapat membeli dan menjual produk, baik baru maupun bekas, seperti sepeda, ponsel, perlengkapan bayi, gadget, aksesoris, komputer, perlengkapan rumah tangga, busana, elektronik, dan lain-lain.

Ketiga e-commers tersebut merupakan bentuk bagian ketiga antara penjual atau pelapak dan pembeli. Dalam e-commers tersebut platfoam yang disediakan memberikan fasilitas keamaan uang yang ditransfer dan barang yang dikirim menjadi aman untuk kedua belah pihak karena sistem yang diberikan dan dijalakan berdasarkan pembelian oleh pembeli yang memilih barang dalam salah satu toko virtual kemudian dikonfirmasi otomatis oleh sistem (Bukalapak, Tokopedia, Lazada) ketika barang sudah terkonfirmasi dan dibayar oleh pembeli dalam hal ini pembayaran dilakukan direkening e-commers tersebut bukan di rekening penjual dalam toko virtual, ketika barang dikirim dan telah sampai kepada pembeli maka pembeli mengkonfirmasi barang telah diterima sehingga uang pembelian yang ditahan 
oleh Bukalapak, Tokopedia, Lazada dapat diteruskan kepada pelapak dan apabila pembeli tidak mengkonfirmasi maka secara otomatis dalam jangka waktu yang sudah ditentukan dalam sistem tersebut uang akan diteruskan kepada pelapak. Sebaliknya ketika barang belum sampai pada batas waktu yang ditentukan maka pembeli dapat komplain dan meminta pengembalian uang kepada e-commers tersebut dan ada opsi untuk barang belum diterima, sehingga keamaan antara penjual dan pembeli dapat merasa aman diantara keduanya.

\section{METODE PENELITIAN}

Jenis Penelitian

Penelitian ini merupakan penelitian hukum normatif atau penelitian hukum doktrinal yang pengkajiannya didasarkan pada kumpulan bahan-bahan yang berasal dari bahan hukum primer ataupun bahan hukum sekunder yang berkaitan dengan objek penelitian.

\section{Pendekatan Penelitian}

Pendekatan penelitian dengan mengkaji asas-asas hukum antara lain Asas Konstitutif yaitu azas yang harus ada dalam kehidupan suatu sistes hukum atau disebut asas hukum umum. Asas regulatif yaitu asas yang diperlukan untuk dapat berprosesnya suatu sistem hukum tersebut $^{5}$ yang berkaitan dengan doktrin hukum maupun hukum positif.

\section{Sumber Bahan Hukum}

Sumber bahan hukum yang dipakai adalah; Kitab Undang-Undang Hukum Perdata, Undang-Undang Nomor 8 Tahun 1999 tentang Perlindungan Konsumen, Undang-Undang Nomor 7 Tahun 2014 tentang perdagangan. Sumber hukum lain berasal dari jurnal-jurnal penelitian,

\footnotetext{
${ }^{5}$ Soerjono Soekanto, Penelitian Hukum Normatif, Raja Grafindo , 2009, hlm 45
}

kamus hukum dan bahan hukum lain yang berkaitan dengan objek penelitian.

\section{Prosedur Pengumpulan Bahan Hukum \\ Pengumpulan bahan hukum yang digunakan adalah studi kepustakaan dengan sumber refrensi yang berkaitan dengan hukum perlindungan konsumen maupun sumber yang dari internet dan media cetak ataupun elektronik yang mendukung penelitian.}

\section{Analisa Bahan Hukum}

Bahan hukum yang sudah dikaji akan dianalisis dan diidentifikasi kemudian ditentukan pokok isi secara objektif dan sistematis.

\section{PEMBAHASAN}

\section{Regulasi/Pengaturan Jual Beli Online/E-Commerce di Indonesia Sudut Pandang KUHPerdata}

E-Commerce lahir berdasarkan kontrak jual beli yang terjadi secara elektronik antara penjual dan pembeli. Hingga saat ini masih terjadi kekosongan hukum di Indonesia, sebab belum mengakomodir tentang syarat-syarat sahnya suatu kontrak elektronik secara khusus. Namun, prinsip dasar keberlakuan suatu kontrak di Indonesia mengacu pada Pasal 1320 KUHPerdata, sehingga dapat pula diterapkan pada kontrak elektronik. Adapun syarat sahnya perjanjian menurut Pasal 1320

KUHPerdata adalah

1. Sepakat mereka yang mengikatkan dirinya

2. Kecakapan Untuk Membuat Suatu Perjanjian

3. Suatu hal tertentu

4. Suatu sebab yang halal

Berdasarkan pemaparan di atas, $E$ Commerce telah sah menurut hukum sepanjang memenuhi Pasal 1320 KUHPerdata. Syarat pertama dan kedua 
disebut dengan syarat subjektif, sebab melekat kepada pihak-pihak yang terlibat dalam E-Commerce. Sedangkan, syarat ketiga dan keempat merupakan syarat objektif, karena melekat pada objek dalam E-Commerce. Apabila syarat pertama dan/atau syarat kedua tidak dipenuhi, maka kontrak elektronik dapat dibatalkan oleh pihak yang berkepentingan dalam jangka waktu selama 5 (lima) tahun sesuai dengan Pasal 1454 KUHPerdata. Dalam hal syarat ketiga dan/atau syarat keempat tidak dipenuhi, maka kontrak elektronik batal demi hukum atau dianggap tidak pernah ada dan tidak ada dasar untuk menuntut.

\section{Sudut Pandang Undang-Undang Nomor 7 Tahun 2014 tentang Perdagangan}

Dalam Undang-Undang Nomor 7 Tahun 2014 tentang Perdagangan telah diatur mengenai perdagangan elektronik yang termuat dalam Pasal 1 angka 24 yang menyatakan bahwa "Perdagangan melalui Sistem Elektronik adalah Perdagangan yang transaksinya dilakukan melalui serangkaian perangkat dan prosedur elektronik". Selanjutnya dalam pasal 65 ayat (1) dijelaskan bahwa "Setiap Pelaku Usaha yang memperdagangkan Barang dan/atau Jasa dengan menggunakan sistem elektronik wajib menyediakan data dan/atau informasi secara lengkap dan benar", serta ayat (2) dinyatakan bahwa "Setiap Pelaku Usaha dilarang memperdagangkan Barang dan/atau Jasa dengan menggunakan sistem elektronik yang tidak sesuai dengan data dan/atau informasi sebagaimana dimaksud pada ayat (1) serta dalam ayat (4) dijelaskan mengenai beberapa data dan/atau informasi yang dimaksud dalam ayat (1) yang memuat persyaratan antara lain: a) identitas dan legalitas Pelaku Usaha sebagai produsen atau Pelaku Usaha Distribusi; b) persyaratan teknis barang yang ditawarkan; c) persyaratan teknis atau kualifikasi jasa yang ditawarkan; d) harga dan cara pembayaran barang dan/atau jasa; dan e) cara penyerahan barang.

\section{Perlindungan Hukum Terhadap Konsumen dalam Jual Beli Online di Indonesia Menurut Undang-Undang Nomor 8 Tahun 1999 tentang Perlindungan Konsumen}

Penjual dalam bisnis jual beli online, biasanya memasang gambar di situs website atau dalam media lainnya dengan menyertakan informasi kriteria barang tersebut serta harganya sehingga konsumen dapat melihat dan jika tertarik dengan barang tersebut, maka pembeli dapat menghubungi melalui nomor kontak yang dicantumkan dalam situs tersebut. Terkadang dalam transaksi jual beli online ini, pembeli harus membayar terlebih dahulu, kemudian barang yang dibeli dikirim ke pembeli. Sehingga jika barang sudah di tangan pembeli dan ternyata tidak sesuai seperti yang ada digambar atau kriteria, maka pembeli tidak dapat komplain dan terpaksa harus tetap diterima karena sudah terlanjur membayar.

Rawannya penipuan dalam bisnis jual beli online yang disebabkan karena ada beberapa pihak yang tidak bertanggung jawab atas segala barang yang dijual Maka dari itu bisnis jual beli online bisa berjalan dengan baik apabila si penjual benar-benar jujur dalam menjual barang yang akan dijualnya. Selain itu dalam melakukan transaksi jual beli online, penjual dan pembeli akan membutuhkan pihak ketiga untuk melakukan penyerahan barang yang dilakukan oleh pedagang dan penyerahan uang yang dilakukan oleh pembeli. 
Transaksi jual beli online memang mudah dan cepat tanpa harus bertatap muka dengan penjual, tetapi pembeli tidak dapat melihat langsung kondisibarang yang ingin dibeli. Jika dalam transaksi tersebut terdapat kecurangan atau pihak penjual melakukan suatu wanprestasi, maka dapat dikenakan sanksi yang sesuai. Sehingga konsumen mendapat perlindungan hukum yang jelas.

Dalam transaksi jual beli online sering timbul permasalahan akibat dari ketidakpuasan salah satu pihak atau kedua belah pihak, dan ini biasanya disebut dengan sengketa konsumen. Jika terjadi sengketa antar konsumen, maka hal tersebut dapat dilakukan dengan cara musyawarah antara pelaku usaha dan konsumen untuk mencapai kesepakatan mengenai ganti ruginya. Jika dengan penyelesaian secara musyawarah belum mencapai mufakat maka penyelesaian sengketa dapat diselesaikan melalui jalur hukum atau pengadilan.

\section{PENUTUP}

Simpulan

Dari hasil pembahasan penelitian tersebut diatas yang berjudul, Perlindungan Hukum Terhadap Konsumen dalam Jual Beli secara Online menurut Undang-Undang Nomor 8 Tahun 1999 tentang Perlindungan Konsumen tersebut dapat disimpulkan:

1) Belum adanya aturan yang mengatur secara khusus tentang perdagangan/belanja/jual beli secara online. Aturan yang saat ini dipakai masih dalam skala KUHPerdata dan Undang-Undang Nomor 7 Tahun 2014 tentang perdagangan yang sifatnya pun masih sangat umum dan belum sepenuhnya menjangkau secara luas dan eskplisit mengenai perlindungan dan aturan khusus konsumen maupun pelaku usaha;

2) Oleh karena belum adanya aturan khusus tersebut maka perlindungan terhadap konsumen maupun rambu-rambu yang ditetapkan kepada pelaku usaha ditekankan pada Undang-Undang Nomor 8 Tahun 1999 tentang Perlindungan Konsumen yang diatur mengenai hak dan kewajiban konsumen serta aturan yang mengatur tentang pertanggung jawaban secara materiil maupun secara yuridis terhadap pelaku usaha yang mempunyai iktikad tidak baik.

\section{Saran}

1) Perlu dibentuknya aturan khusus atau perundang-undangan khusus tentang jual beli online sehingga lebih terjaminnya hak-hak dan kewajiban konsumen agar ada payung hukum yang jelas bagi semua fihak;

2) Perlu adanya pengawas perdagangan online yang disistem secara online pula sehingga hal tersebut dapat meminimalisir segala bentuk penipuan maupun segala bentuk kejahatan dan memaksimalkan perlindungan baik kepada konsumen maupun kepada pelaku usaha.

\section{DAFTAR PUSTAKA}

Akbar, Ali. 2016. Kamus Praktis Internet Untuk Semua Orang, Neomedia Press, Semarang .

Barkatullah Halim Abdul dan Teguh Prasetyo, 2005. Bisnis ECommerce: Studi Sistem Keamanan 
dan Hukum di Indonesia. Yogyakarta, Pustaka Pelajar.

Edmon Makarim. 2004. Kompilasi Hukum Telematika, Jakarta: PT. Raja Grafindo Persada.

Indrajit Richardus Eko. 2001. ECommerce: Kiat dan Strategi Bisnis di Dunia Maya, Jakarta, PT. Elex Media Komputindo.

Departemen Komunikasi dan Informatika. 2017. Republik Indonesia, Menuju Kepastian Hukum di Bidang Informasi dan Transaksi Elektronik, Jakarta.

http://www.blogester.com/artikelelekoind rajit/mekanisme-transaksipembayaran.Diakses 24 Agustus $\underline{2018}$

Kiswanto, Heru. 2018. Keabsahan Perjanjian Jual Beli Benda Bergerak melalui Internet (Tinjauan dari Buku III KUH Perdata dan UU No.19 Tahun 2016).

Miru Ahmadi \& Sutarman Yodo. 2011. Hukum Perlindungan Konsumen, Jakarta, PT. Raja Wali Grafindo Persada.

Mustofa Imam. 2015. Fiqih Mu'amalah Kontemporer, Yogyakarta: Kaukaba Dipantara.

Samsuri Hendra. 2011. Perkembangan ECommerce di Indonesia, Universitas Gajah Mada Diaskes melalui academia.edu.

Sanjaya Ridwan dan WisnuSanjaya, 2009. Membangun Kerajaan Bisnis Online, (Tuntutan Praktis Pebisnis
Online), Jakarta: Kompas Gramedia).

Sidabalok Jayus. 2014. Hukum Perlindungan Konsumen di Indonesia, Bandung, PT. Citra Aditya Baki.

Didit Agus Irwantoko, 2014. www.belanjaonline.co.id Pengaruh strategi promotion mix dalam meningkatkan penjualan pakaian secara online di kalangan remaja kota Madiun, Jurnal Ekomaks Vol. 3 Nomor 2 September.

Emilda Kuspraningrum, Keabsahan Kontrak Elektronik Dalam UU ITE Ditinjau Dari Pasal 1320 KUHPerdata dan UNCITRAL Model Law On Electronic

Commerce, Risalah HUKUM Fakultas Hukum Unmul Vol. 7, No. 2, Desember, hlm.182 - 194.

Imam Mustofa. 2012. "Transaksi Elektronik (E-Commerce) Dalam Perspektif Fikih", Jurnal Hukum Islam, ( Pekalongan: Stain Pekalongan, Volume 10, No. 2, Desember)

Undang-Undang Nomor 8 Tahun 1999 Tentang Perlindungan Konsumen

Undang-Undang Nomor 7 Tahun 2014 Tentang Perdagangan KUHPerdata

https://www.bukalapak.com/terms Cara Transaksi di Bukalapak.

https://id.wikipedia.org/wiki/Belanja_dari ng\#Perkembangan_belanja_daring_ di_Indonesia. 
http://repository.wima.ac.id/3396/2/Bab

Online di Indonesia.

\%201.pdf Perkembangan Belanja 